\title{
Association of Erythromycin Resistance with the mefA and ermB Genes among Clinical Isolates of Streptococcus pneumoniae in Tehran, Iran
}

\author{
İran, Tahran'daki Streptococcus pneumoniae Klinik Izolatları Arasında Eritromisin Direncinin \\ mefA ve ermB Genleri ile İlişkilendirilmesi
}

\author{
(1) Fatemeh FALLAH ${ }^{1,2}$, (1) Sedigheh Rafiei TABATABAEI ${ }^{2}$, (1) Masoud YOUSEFI ${ }^{3}$, (1) Ali HASHEMI ${ }^{1}$, (1) Ali NAZARI-ALAM ${ }^{4}$, (1) Ata SAADAT ${ }^{1}$ \\ 1Shahid Beheshti University of Medical Sciences, School of Medical, Department of Microbiology, Tehran, Iran \\ 2Shahid Beheshti University of Medical Sciences, Mofid Children's Hospital, Pediatric Infections Research Center, Tehran, Iran \\ ${ }^{3}$ Birjand University of Medical Sciences, Infectious Diseases Research Center, Birjand, Iran \\ ${ }^{4}$ Kashan University of Medical Sciences, School of Medicine, Department of Microbiology, Kashan, Iran
}

\section{Abstract}

Introduction: Streptococcus pneumoniae is one of the major pathogens responsible for respiratory tract infections, meningitis, and bacteremia. In most countries around the world, an increase in the emergence of macrolide-resistant $S$. pneumoniae isolates has become a serious problem. Therefore, this study was conducted to investigate the association of erythromycin resistance with the mefA and ermB genes among clinical isolates of S. pneumoniae in Tehran City (Tehran Province, Iran).

Materials and Methods: In this cross-sectional study, 62 erythromycin-resistant S. pneumoniae (ERSP) isolates were obtained from patients in four hospitals in Tehran city during 2013-2015. The macrolide resistance genes mefA and ermB were detected in ERSP isolates using polymerase chain reaction (PCR) assays. Furthermore, the copy number and expression level of the mefA gene were determined by real-time PCR.

Results: In the present study, the overall resistance to erythromycin in S. pneumoniae isolates was 84.93\% (62 isolates out of 73). Either mefA or ermB was identified in 10 (16.13\%) and 36 (58.06\%) ERSP isolates, respectively, and 7 (11.29\%) ERSP isolates harbored both genes. Comparison of the mean relative expression of the $m e f A$ gene in ERSP isolates with different erythromycin minimal inhibitory concentration (MIC) values indicated that the expression level was increased approximately twofold for each doubling of the MIC value.

Conclusion: Our findings highlighted the dominance of ribosomal methylation encoded by erm $B$ as the most common mechanism of macrolide resistance in clinical S. pneumoniae isolates from Iran. Furthermore, in the present study, the expression levels of the mefA gene showed a significant increase in the ERSP isolates with higher erythromycin MIC values.

Keywords: Streptococcus pneumoniae, erythromycin resistance, resistance genes, polymerase chain reaction, Iran

\section{$\ddot{0} z$}

Giriş: Streptococcus pneumoniae, solunum yolu enfeksiyonları, menenjit ve bakteremiden sorumlu başlıca patojenlerden biridir. Dünya ülkelerinin çoğunda makrolide dirençli S. pneumoniae izolatlarının ortaya çıkışındaki artış ciddi bir sorun haline gelmiştir. Bu nedenle, bu çalışma Tahran'daki (Tahran Şehri, İran) S. pneumoniae'nin klinik izolatları arasında eritromisin direncinin mefA ve ermB genleri ile ilişkisini araştırmak için yapılmıştır.

Cite this article as: Fallah F, Tabatabaei SR, Yousefi M, Hashemi A, Nazari-Alam A, Saadat A. Association of Erythromycin Resistance with the mefA and ermB Genes among Clinical Isolates of Streptococcus pneumoniae in Tehran, Iran. Mediterr J Infect Microb Antimicrob. 2021;10:19.

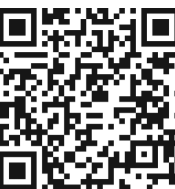

Address for Correspondence/Yazışma Adresi: Ali Nazari-Alam PhD, Department of Microbiology, Faculty of Medicine

Kashan University of Medical Sciences, Kashan, Iran

Phone: +983155540021-5 E-mail: nazarialam-a@kaums.ac.ir

Received/Geliş Tarihi: 28.10.2020 Accepted/Kabul Tarihi: 19.03.2021 ORCID ID: orcid.org/0000-0003-4770-5836

${ }^{\circ}$ Copyright 2021 by the Infectious Diseases and Clinical Microbiology Specialty Society of Turkey

Mediterranean Journal of Infection, Microbes and Antimicrobials published by Galenos Yayinevi. 
Gereç ve Yöntem: Bu kesitsel çalışmada, 2013-2015 yılları arasında Tahran'daki dört hastanedeki hastalardan 62 eritromisine dirençli S. pneumoniae izolatı elde edilmiştir. Makrolid direnç genlerinden mefA ve ermB, eritromisine dirençli S. pneumoniae (ERSP) izolatlarında polimeraz zincir reaksiyonu (PCR) testlerini kullanarak tespit edilmiştir. Ayrıca mefA geninin kopya sayıları ve ekspresyon düzeyi real-time PCR yöntemi ile belirlenmiştir.

Bulgular: Bu çalışmada, S. pneumoniae izolatlarında eritromisine genel direnç \%84,93 (73 izolattan 62'si) olarak bulunmuştur. Sonuçlara göre mefA ve ermB genlerinden biri sırasıyla $10(\% 16,13)$ ve $36(\% 58,06)$ ERSP izolatında tanımlandı. Yedi $(\% 11,29)$ ERSP izolatı hem mefA hem de ermB genlerini barındırdı. Farklı eritromisin minimal inhibitör konsantrasyon (MIC) değerlerine sahip ERSP izolatlarında mefA geninin ortalama nispi ekspresyonunun karşılaştırıması; ekspresyon seviyelerinin, MIC değerlerinin her iki katına çıkması için yaklaşık iki kat arttığını gösterdi.

Sonuç: Bulgularımız, İran'daki klinik S. pneumoniae izolatlarında makrolid direncinin en yaygın mekanizması olarak ermB tarafından kodlanan ribozomal metilasyonun baskınlığını vurguladı. Ayrıca, bu çalışmada mefA geninin ekspresyon seviyeleri, daha yüksek eritromisin MıC değerlerine sahip ERSP izolatlarında anlamlı bir artış göstermiştir.

Anahtar Kelimeler: Streptococcus pneumoniae, eritromisin direnci, direnç genleri, polimeraz zincir reaksiyonu, İran

\section{Introduction}

Streptococcus pneumoniae (Pneumococcus) is an ordinary resident of the human upper respiratory tract, but it may cause a wide variety of infections in children and adults, ranging from pneumonia, meningitis, otitis media, septicemia, sinusitis, and septic arthritis to relatively benign soft-tissue infections ${ }^{[1-3]}$.

Macrolides are commonly used as first-line agents for the empirical treatment of community-acquired pneumonia (CAP), and their combination with a beta-lactam is recommended for severe pneumonia. However, treatment of pneumococcal infections has become challenging due to the ever-increasing emergence of macrolide-resistant S. pneumoniae ${ }^{[4-6]}$.

Resistance of $S$. pneumoniae isolates to macrolides was identified in the late 1980s. Two main macrolide resistance mechanisms have been described in S. pneumoniae: target-site modification and active efflux of the drug out of the bacterium. Target-site modification is mediated by an rRNA-methylating enzyme and is coded by the ermB gene, resulting in coresistance to macrolide, lincosamide, and streptogramin B antibiotics (MLSB resistance) ${ }^{[7,8]}$. The macrolide efflux pump (M phenotype) is encoded by the mefA gene, and bacterial isolates with this phenotype are resistant to erythromycin, clarithromycin, and azithromycin. High-level macrolide resistance is commonly associated with the ermB gene, whereas the mefA gene usually results in a lower level of resistance ${ }^{[9,10]}$. It is noteworthy that the prevalence of the two main macrolide resistance mechanisms in pneumococci varies depending on the local epidemiology; thus, erm $B$-mediated ribosomal methylation commonly occurs in European countries, while macrolide-specific efflux pumpmediated resistance is clinically relevant in the USA ${ }^{[8,11]}$.

Molecular epidemiological information on antibiotic resistance patterns and mechanisms of resistance can help to prevent and treat infectious diseases, such as multidrug-resistant $S$. pneumoniae infections ${ }^{[12,13]}$. Given that widespread distribution of macrolide and multidrug resistance in clinical S. pneumoniae isolates is a major concern, the need for extensive research is greater than ever. Accordingly, this study was performed to investigate the association of erythromycin resistance with the $m e f A$ and ermB genes among clinical isolates of $S$. pneumoniae in Tehran City, Iran.

\section{Materials and Methods}

\section{Study Design and Bacterial Isolates}

In this cross-sectional study, 62 non-duplicate erythromycinresistant $S$. pneumoniae (ERSP) isolates were collected from patients in four hospitals in Tehran City from December 2015 to July 2017. The isolates were obtained from various clinical samples including cerebrospinal fluid (CSF), blood, sputum, eye swabs, nasal discharge, bronchoalveolar lavage (BAL), and other body fluids (brain abscesses, synovial fluid, throat swabs, and abdominal fluid). The study was approved by the Executive Board of the Shahid Beheshti University of Medical Sciences (Tehran Province, Iran). This study was a retrospective, laboratory based study; therefore, there was no need to obtain informed written consent from the patients.

The S. pneumoniae isolates were identified by conventional microbiological methods and biochemical testing (hemolysis, Gram staining, susceptibility to optochin disc [MAST, UK], and solubility in bile) ${ }^{[14]}$. Polymerase chain reaction (PCR) assays were used to confirm diagnosis of $S$. pneumoniae infection in isolates by detecting the cpsA target gene.

\section{Erythromycin-Resistant S. pneumoniae Isolates}

Erythromycin-resistant $S$. pneumoniae isolates [minimal inhibitory concentration (MIC) $\geq 1 \mu \mathrm{g} / \mathrm{ml}$ ] were identified using the broth microdilution method according to the clinical and laboratory standards institute guidelines ${ }^{[15]}$. The MIC values were read visually as the lowest concentration of the antimicrobial agent that prevented visible growth. S. pneumoniae ATCC 49619 was used as a standard strain.

\section{Detection of the mefA and ermB Genes}

Polymerase chain reaction assays were used to detect the mefA and ermB genes in ERSP isolates with specific primers (Table 1). 
The primers were designed in the present study using PrimerBLAST [National Center for Biotechnology Information (NCBI), USA] and primer3 software. Genomic DNA was extracted from pure cultures of the strains using the High Pure PCR Template Preparation Kit according to the manufacturer's instructions.

Polymerase chain reaction was conducted in a final volume of $25 \mu \mathrm{l}$ using the HotStar Taq Master Mix kit containing $12.5 \mu \mathrm{l}$ of $2 \times$ HotStar Taq Master Mix (containing $3 \mathrm{mM} \mathrm{MgCl}, 0.4 \mathrm{mM}$ of each dNTP, and $0.08 \mathrm{U} / \mu \mathrm{l}$ Taq DNA polymerase in reaction buffer), $1 \mu \mathrm{l}$ of the DNA template, $1 \mu \mathrm{l}$ of each primer (20 pmol), and $9.5 \mu \mathrm{l}$ of ddH20. DNA amplification was performed in a thermocycler with an initial denaturation step at $95{ }^{\circ} \mathrm{C}$ for 5 minutes; 30 amplification cycles of 30 seconds at $95{ }^{\circ} \mathrm{C}, 30$ seconds at different temperatures for different genes, and 40 seconds at $72{ }^{\circ} \mathrm{C}$; followed by an additional extension step of 7 minutes at $72{ }^{\circ} \mathrm{C}$. The amplified products were separated by electrophoresis through 1\% agarose gel and visualized by RedSafe staining.

DNA sequencing of nine $S$. pneumoniae isolates randomly selected from each of the resistance genotypes (mefA, ermB, and $m e f A+e r m B$ ) was performed by Bioneer Corporation (South Korea), and the obtained sequence data were aligned using the BLAST program and compared with the GenBank database in the NCBlational CenterBiotechnology Information.

\section{Expression Levels of the mefA Gene}

The copy number and expression level of the mefA gene were determined in ERSP isolates by real-time PCR.

RNA extraction from the isolates was performed using the High Pure RNA Isolation Kit according to the manufacturer's instructions. The RNA was treated with DNase using DNase I to remove any remaining genomic DNA, and complete removal of contaminating DNA was confirmed by PCR. Reverse transcription was performed using the PrimeScript RT reagent Kit for 15 minutes at $37^{\circ} \mathrm{C}$, the enzyme was inactivated for 5 seconds at $85^{\circ} \mathrm{C}$, and then the reaction was cooled.

Synthesized complementary DNA was amplified by quantitative real-time PCR (qPCR) using a Rotor-Gene $6000^{\mathrm{TM}}$ Real-Time
PCR System. Real-time PCR amplification was performed in a volume of $25 \mu \mathrm{l}$ containing $12.5 \mu \mathrm{l}$ of Power SYBR ${ }^{\circ}$ Green PCR Master Mix, $1 \mu \mathrm{l}$ of each primer ( $50 \mathrm{pmol} / \mu \mathrm{l}), 2 \mu \mathrm{l}$ of cDNA, and $8.5 \mu \mathrm{l}$ of DNase free $\mathrm{ddH} 2 \mathrm{O}$. The amplification conditions for real-time PCR assays were as follows: initial denaturation at 95 ${ }^{\circ} \mathrm{C}$ for 30 seconds, followed by 40 cycles of $95^{\circ} \mathrm{C}$ for 7 seconds, $53{ }^{\circ} \mathrm{C}$ for 20 seconds, and $60{ }^{\circ} \mathrm{C}$ for 25 seconds. Triplicates of a negative control were included in all qPCR runs, and 16s rRNA was used as an endogenous control. The primers used in this study are described in Table 1. Amplification data were analyzed using the software.

\section{Statistical Analysis}

The data were entered and analyzed using SPSS statistical software. Frequencies and percentages were calculated, the Pearson chi-square test and analysis of variance were performed as appropriate, and $p$ values of less than 0.05 were regarded as statistically significant.

\section{Results}

Erythromycin-Resistant S. pneumoniae Isolates

In the present study, 62 ERSP isolates (MIC $\geq 1 \mu \mathrm{g} / \mathrm{ml}$ ) were collected from various clinical samples including CSF (13 isolates, $21 \%)$, blood (12 isolates, 19.4\%), sputum (13 isolates, $21 \%$ ), eye swabs (3 isolates, 4.8\%), nasal discharge (2 isolates, 3.2\%), BAL (5 isolates, 8.1\%), and other body fluids (14 isolates, 22.6\%). It is noteworthy that the overall prevalence of resistance to erythromycin in S. pneumoniae isolates was 84.93\% (62 isolates out of 73).

The MIC values of erythromycin for the ERSP isolates in the susceptibility test were determined using the broth microdilution method as shown in Table 2.

\section{Frequency of the mefA and erm $B$ Genes}

In this study, the mefA and erm $B$ genes were detected in ERSP isolates by PCR assays. Either of the mefA and erm $B$ genes were identified in $10(16.13 \%)$ and $36(58.06 \%)$ ERSP isolates, respectively. It is noteworthy that $7(11.29 \%)$ isolates harbored

Table 1. Polymerase chain reaction (PCR) and real-time PCR primers used in this study

\begin{tabular}{|c|c|c|c|c|}
\hline Gene & Primer sequence $\left(5^{\prime}-3^{\prime}\right)$ & Annealing $\left({ }^{\circ} \mathrm{C}\right)$ & Products sizes (bp) & Ref. \\
\hline $\operatorname{cps} A-\mathrm{F}$ & GCAGTACAGCAGTIGTIGAACTGACC & 50 & 160 & Tabatabaei et al. ${ }^{[5]}$ \\
\hline $\operatorname{cps} A-\mathrm{R}$ & GAATAПTTCATTATCAGTCCCAGTC & & & \\
\hline $\mathrm{ermB}-\mathrm{F}$ & CGACGAAACTGGCTAAAATA & 58 & 331 & This study \\
\hline ermB-R & АATTGCTGAATCGAGACTTG & & & \\
\hline mefA-F & GGTGTGCTAGTGGATCGTC & 53 & 188 & This study \\
\hline mefA-R & GTAACCGCATGAGAGCCG & & & \\
\hline 16s rRNA-RT-F & CTGTGGCTTAACCATAGTAG & 55 & 91 & Al-Yassari ${ }^{[16]}$ \\
\hline 16s rRNA-RT-R & СТАCGCAПTСАССGCTACA & & & \\
\hline
\end{tabular}


both genes simultaneously, and 9 (14.52\%) isolates had neither of the genes (Table 3).

Finally, the nucleotide sequence data reported here have been submitted to the GenBank sequence database, and the accession numbers KU739787, KU739788, KU739789, and KU739790 for the mefA gene and KT758056 for the ermB gene have been assigned. Statistical analysis showed that there was no significant relationship between the presence of the mefA and $\mathrm{erm} B$ genes and the MIC values for erythromycin in clinical ERSP erythromycin-resistant $S$. pneumoniae isolates ( $p$ value $=$ 0.616) (Table 3).

\section{Expression Levels of the mefA Gene}

Comparison of mean relative expression of the mefA gene in ERSP isolates with different erythromycin MIC values (ranging between 8 and $32 \mu \mathrm{g} / \mathrm{ml}$ ) indicated that expression levels were increased by approximately twofold for each doubling of MIC values $(p<0.05)$ (Figure 1).

\section{Discussion}

Macrolides are currently recommended as the mainstay of treatment for empirical therapy of CAP. However, the emergence of macrolide-resistant $S$. pneumoniae isolates has increased over the past decade, and clinical failure of macrolide treatment in pneumococcal infections has been reported in various parts of the world. Notably, studies have shown that macrolide resistance in pneumococcal infections has remained a serious problem in many Asian countries ${ }^{[11-13]}$.

Target modification by a ribosomal methylase encoded by the ermB gene and drug efflux encoded by the mef gene are two major mechanisms mediating resistance to macrolides in S. pneumoniae. The macrolide-specific efflux mechanism is clinically relevant in macrolide-resistant pneumococci in North
America, whereas ermB-mediated ribosomal methylation has been found in more than $80 \%$ of ERSP isolates in most European countries $^{[11,17]}$.

In the present study, 62 ERSP isolates $(\mathrm{MIC} \geq 1 \mu \mathrm{g} / \mathrm{ml})$ were collected from various clinical samples. The distribution rates of the mefA and ermB genes in ERSP isolates were 16.13\% and $58.06 \%$, respectively. These results are consistent with many reports from Asian countries such as China, Taiwan, Sri Lanka, and Korea, as well as most other studies conducted in Iran, showing that ribosomal methylation encoded by ermB is the most common mechanism of resistance in ERSP isolates ${ }^{[11,18]}$. In contrast, in some studies from Hong Kong, Singapore, Thailand,

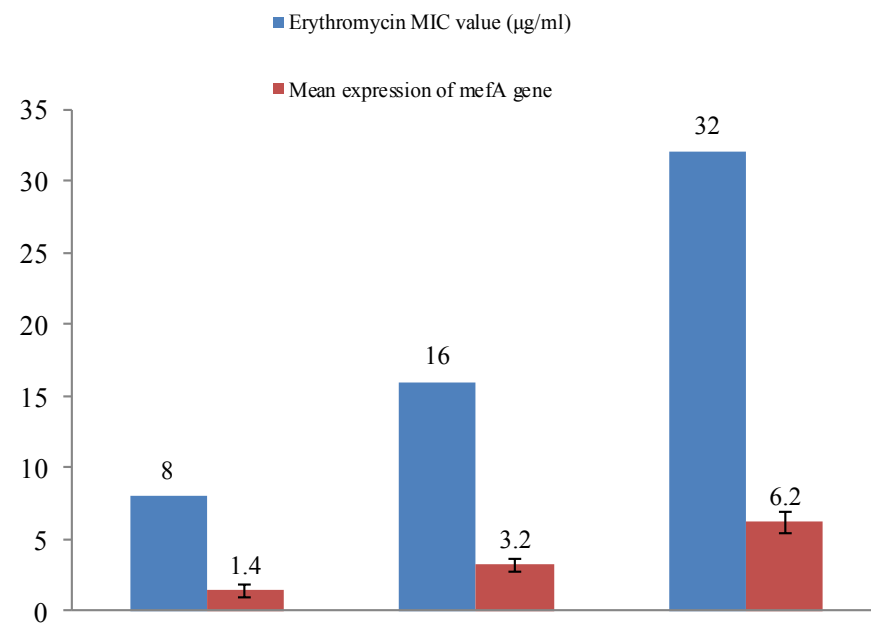

Figure 1. Mean relative expression of the mefA gene in clinical erythromycin-resistant $S$. pneumoniae isolates with different erythromycin MIC values $(p<0.05)$. 16s rRNA was used as an endogenous control

MIC: Minimal inhibitory concentration

Table 2. MIC values of erythromycin for 62 clinical erythromycin-resistant S. pneumoniae isolates

\begin{tabular}{|c|c|c|c|c|c|c|}
\hline \multirow[t]{2}{*}{ ERSP isolates } & \multicolumn{6}{|c|}{$\mathrm{MIC}(\mu \mathrm{g} / \mathrm{ml})$} \\
\hline & 1 & 2 & 4 & 8 & 16 & 32 \\
\hline No. of isolates (\%) & $10(16.13)$ & $7(11.29)$ & $4(6.45)$ & $11(17.74)$ & $16(25.81)$ & $14(22.58)$ \\
\hline
\end{tabular}

ERSP: Erythromycin-resistant Streptococcus pneumoniae, MIC: Minimal inhibitory concentration

Table 3. Relationship between the presence of the mefA and ermB genes with the MIC values for erythromycin in clinical erythromycin-resistant $S$. pneumoniae isolates

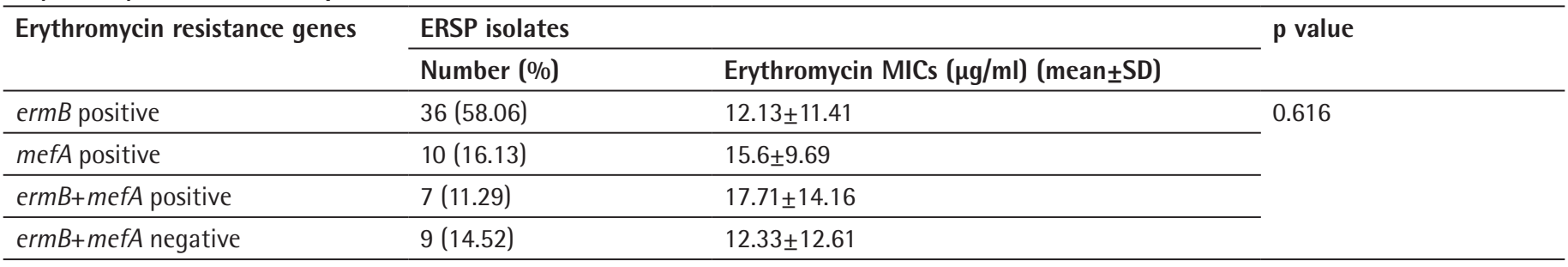

ERSP: Erythromycin-resistant Streptococcus pneumoniae, MIC: Minimal inhibitory concentration, SD: Standard deviation 
and Malaysia, the macrolide-specific efflux encoded by mefA was more common in erythromycin-resistant isolates ${ }^{[11]}$. Overall, the dominance of each of the two major macrolide resistance mechanisms in S. pneumoniae isolates from Asian countries seems to differ on the basis of geographical area. Notably, in ERSP isolates lacking the mefA and erm $B$ genes, other genes involved in macrolide resistance may have induced erythromycin resistance.

As mentioned earlier, active macrolide efflux is one of the major mechanisms of macrolide resistance in S. pneumoniae in many parts of the world. The use of relative real-time PCR assay allows for the characterization of macrolide-specific efflux gene expression in macrolide-resistant $S$. pneumoniae isolates ${ }^{[19,20]}$. In this study, the expression level of the mefA gene in ERSP isolates was determined by real-time PCR. A comparison of mean relative expression of the mefA gene in ERSP isolates with different erythromycin MIC values indicated that expression levels were increased approximately twofold for each doubling of the MIC value. Similar findings have also been reported in rare studies conducted elsewhere. Wierzbowski et al. ${ }^{[2]}$ indicated that higher expression levels of the mefE gene were associated with higher MICs of erythromycin in ERSP isolates. Although these results highlight the association between increased expression of macrolide-specific efflux genes and higher levels of macrolide resistance in S. pneumoniae, there is an apparent need for further studies in this area. Considering the sample size limit, one of the limitations of this study was the lack of investigation of high-level erythromycin-resistant isolates (with MICs for erythromycin usually $\geq 256 \mu \mathrm{g} / \mathrm{ml}$ ).

\section{Conclusion}

Our findings revealed a dominance of ribosomal methylation encoded by the ermB gene as the most common mechanism of macrolide resistance in clinical $S$. pneumoniae isolates from Iran. Furthermore, in the present study, increased expression of the mefA gene was associated with higher levels of macrolide resistance in macrolide-resistant S. pneumoniae isolates. Finally, it is suggested that further studies be conducted in order to investigate the role of macrolide-specific efflux pumps in increasing levels of macrolide resistance in S. pneumoniae.

\section{Ethics}

Ethics Committee Approval: The study was approved by the executive board of Shahid Beheshti University of Medical Sciences (decision date-number: 2015/10-28).

Informed Consent: Since this was a retrospective laboratory based study, informed consent was not received.

Peer-review: Externally and internally peer-reviewed.

\section{Authorship Contributions}

Surgical and Medical Practices: F.F., S.R.T., M.Y., A.H., A.N.A., A.S., Concept: F.F., S.R.T., M.Y., A.H., A.N.A., A.S., Design: F.F., S.R.T., M.Y., A.H., A.N.A., A.S., Data Collection or Processing: F.F., S.R.T., M.Y., A.H., A.N.A., A.S., Analysis or Interpretation: F.F., S.R.T., M.Y., A.H., A.N.A., A.S., Literature Search: F.F., S.R.T., M.Y., A.H., A.N.A., A.S., Writing: F.F., S.R.T., M.Y., A.H., A.N.A., A.S.

Conflict of Interest: No conflict of interest was declared by the authors.

Financial Disclosure: This study was a part of the Ph.D. thesis of the first author and was supported and approved by Shahid Beheshti University of Medical Sciences (grant number: 420).

\section{References}

1. Taha N, Araj GF, Wakim RH, Kanj SS, Kanafani ZA, Sabra A, Khairallah MT, Nassar FJ, Shehab M, Baroud M, Dbaibo G, Matar GM. Genotypes and serotype distribution of macrolide resistant invasive and non-invasive Streptococcus pneumoniae isolates from Lebanon. Ann Clin Microbiol Antimicrob. 2012;11:2.

2. Houri $H$, Tabatabaei SR, Saee Y, Fallah F, Rahbar M, Karimi A. Distribution of capsular types and drug resistance patterns of invasive pediatric Streptococcus pneumoniae isolates in Teheran, Iran. Int J Infect Dis. 2017;57:21-6.

3. Li MC, Wang $Y$, Zhang $H$, Liu $Y$, Chen $X J$, Yang HW, Ma P, Wang DC, Zhang BC, Dong AY, Wang CX, Li Y, Bai P, Tang WM, Wang J, Shao ZJ, $\mathrm{Xu}$ YC. Serotype distribution and clinical characteristics associated with Streptococcus pneumoniae among Chinese children and adults with invasive pneumococcal disease: a multicenter observational study. Hum Vaccin Immunother. 2021;17:146-56.

4. Cheng $A C$, Jenney AWJ. Macrolide resistance in pneumococci-is it relevant? Pneumonia (Nathan). 2016;8:10.

5. Tabatabaei SR, Rahbar M, Alam AN, Fallah F, Hashemi A, Yousefi M, Houri H, Karimi A. Detection of pbp2b gene and antimicrobial susceptibility pattern of Streptococcus pneumoniae isolates in Tehran hospitals, Iran. Arch Pediatr Infect Dis. 2016;5:e38891.

6. Alam AN, Tabatabaii SR, Hashemi A, Yousefi $M$, Alfatemi SMH Characterization of 5 Episodes of Vancomycin Nonsusceptible Streptococcus pneumoniae From Clinical Isolates in Tehran, Iran. Arch Clin Infect Dis. 2017;12:e57285.

7. Appelbaum PC. Resistance among Streptococcus pneumoniae: Implications for drug selection. Clin Infect Dis. 2002;34:1613-20.

8. Jenkins $S G$, Farrell DJ. Increase in pneumococcus macrolide resistance, United States. Emerg Infect Dis. 2009;15:1260-4.

9. Midouni Ayadi B, Mehiri E, Draoui H, Ghariani A, Essalah L, Raoult D, Fournier PE, Slim-Saidi LN. Phenotypic and molecular characterization of macrolide resistance mechanisms among Streptococcus pneumoniae isolated in Tunisia. J Med Microbiol. 2020;69:505-20.

10. Ko KS, Song JH. Evolution of erythromycin-resistant Streptococcus pneumoniae from Asian countries that contains erm(B) and mef(A) genes. J Infect Dis. 2004;190:739-47.

11. Song JH, Chang HH, Suh JY, Ko KS, Jung SI, Oh WS, Peck KR, Lee NY, Yang $\mathrm{Y}$, Chongthaleong A, Aswapokee N, Chiu CH, Lalitha MK, Perera J, Yee $\Pi$, Kumararasinghe G, Jamal F, Kamarulazaman A, Parasakthi N, Van PH, So T, Ng TK; ANSORP Study Group. Macrolide resistance and genotypic characterization of Streptococcus pneumoniae in Asian countries: a study 
of the Asian Network for Surveillance of Resistant Pathogens (ANSORP). J Antimicrob Chemother. 2004;53:457-63.

12. Mosleh MN, Gharibi M, Alikhani MY, Saidijam M, Vakhshiteh F. Antimicrobial susceptibility and analysis of macrolide resistance genes in Streptococcus pneumoniae isolated in Hamadan. Iran J Basic Med Sci. 2014;17:595-9.

13. Van Bambeke F, Reinert RR, Appelbaum PC, Tulkens PM, Peetermans WE. Multidrug-resistant Streptococcus pneumoniae infections: current and future therapeutic options. Drugs. 2007;67:2355-82.

14. Mahon CR, Lehman DC. Textbook of diagnostic microbiology-E-Book: Elsevier Health Sciences; 2014.

15. Wayne P. Clinical and laboratory standards institute. Performance standards for antimicrobial susceptibility testing. Inform Suppl. 2011;31:100-21.

16. Al-Yassari A-kS. Real-Time PCR For Direct Detection of Streptococcus pneumoniae In Patients Suffering From Upper Respiratory Tract Infection in Babylon Province. Med j Babylon. 2014;11:712-8.
17. Schroeder MR, Stephens DS. Macrolide Resistance in Streptococcus pneumoniae. Front Cell Infect Microbiol. 2016;6:98.

18. Shokouhi S, Alavi Darazam I, Yazdanpanah A. Resistance of Streptococcus pneumoniae to Macrolides in Iran. Tanaffos. 2019;18:104-11.

19. Ambrose KD, Nisbet R, Stephens DS. Macrolide efflux in Streptococcus pneumoniae is mediated by a dual efflux pump (mel and mef) and is erythromycin inducible. Antimicrob Agents Chemother. 2005;49:4203-9.

20. Del Grosso $M$, lannelli $F$, Messina $C$, Santagati $M$, Petrosillo $N$, Stefani $S$, Pozzi G, Pantosti A. Macrolide efflux genes mef(A) and mef(E) are carried by different genetic elements in Streptococcus pneumoniae. J Clin Microbiol. 2002;40:774-8.

21. Wierzbowski AK, Boyd D, Mulvey M, Hoban DJ, Zhanel GG. Expression of the mef(E) gene encoding the macrolide efflux pump protein increases in Streptococcus pneumoniae with increasing resistance to macrolides. Antimicrob Agents Chemother. 2005;49:4635-40. 